\section{Bush's biotech bent}

Discerning President Bush's likely biotechnology policies is still mostly a matter of guesswork. By early January, he named Wisconsin governor Tommy Thompson to head the Department of Health and Human Services and New Jersey governor Christine Whitman to direct the Environmental Protection Agency, but still had not even hinted at who will be the next commissioner of the Food and Drug Administration, which has important biotechnology-related regulatory responsibilities, or the next director of the National Institutes of Health, which invests a great deal of resources in basic and some applied research that brings benefits to the industry. Although Governor Whitman has said little publicly about biotechnology and the environment, Governor Thompson declared "the economic potential for biotechnology and high-technology companies is incredible." Indeed, to attract more investment by the private sector, in early 2000 he announced a new masters degree in biotechnology at the University of Wisconsin (Madison, WI), as well as a \$317 million investment into building biotechnology research centers there.

JF

\section{UK Embryonic stem cell vote}

On 19 December 2000, British members of Parliament (MPs) voted to relax the 1990 Human Fertilization and Embryology Act so as to allow therapeutic cloning. If ratified by the House of Lords, the new law will allow UK researchers to apply for a license from the Human Fertility and Embryology Authority (HFEA; London) to use nuclear transfer technology to create human embryos specifically for research on embryonic stem cells (Nat. Biotechnol. 18, 1034, 2000). This is allowed in the United States if carried out with private funds, but the United Kingdom is the first country in Europe to allow such research-public or private. "We are confident that the Human Embryology and Fertilization Act now provides excellent and balanced regulation in this important area of research where the UK is at the forefront of international work," says Crispin Kirkman, chief executive of the British BioIndustry Association (BIA; London).

Business and Regulatory News Briefs written by Aaron Bouchie, Liz Fletcher, Jeff Fox, Thomas Kowalski, Sabine Louët, Chris Morrisson, and Eric Niiler.

\section{GM crop safety}

Two reports were published in December concerning the effects of transgenic crops on both the environment and food supply. Although one of them finds that GM foods have shown no adverse human health effects, both calls for further study. The first report, sponsored by the American Association for the Advancement of Science (Washington, DC), analyzed 35 peerreviewed studies that examined potential emergence of "superweeds", unintended consequences of the spread of viral diseases, and possible harm to nontarget species, but determined the potential environmental detriments of GM crops to be inconclusive (Science 290, 2088-2093, 2000). Meanwhile, a review by the American Medical Association (AMA; Chicago, IL) noted that 40 transgenic crop varieties have been cleared by the US government, and that crops and food produced using recombinant DNA techniques have been available for 10 years without any long-term human health effects. The AMA recommends science-based regulation of GM crops and continued research into potential environmental risks, but deems the labeling of GM foods unnecessary, because "these foods are substantially equivalent to their conventional counterparts."

EN

\section{Franco-German plant genomics}

On February 21, Genoplante, the French plant genomics laboratory network, and the German counterpart Genomanalyse im Biologischen System Pflanze (GABI) will announce a collaborative effort to develop research projects in plant functional genomics and proteomics. The aim of the joint effort is to eliminate redundant research and consolidate brainpower, thereby strengthening Europe's position in the field. "As far as plant genomics research is concerned, it is only possible to be competitive with the US at the European level," says Michel Caboche, director of Genoplante. The Genoplante-GABI initiative will be co-funded by Genoplante [FF5 million ( $\$ 0.72$ million)] and GABI [DM5 million ( $\$ 2.40$ million)], beginning with a plant genomics database that will be made publicly available this summer. Thomas Altman, GABI project coordinator, says the effort could receive further funding in 2003 from the European Union Framework VI program, which is expected to encompass agricultural genomics.

\section{Incyte acquires Proteome}

On December 21, genomic-content provider Incyte Genomics (Palo Alto, CA) agreed to acquire privately held Proteome (Beverly, MA) for $\$ 77$ million in cash and stock. The merger adds annotation and reference data from Proteome's BioKnowledge Library-covering more than 50,000 human, mouse, rat, worm, yeast, and other model organism proteins-to Incyte's genetic information databases. Whereas Proteome's 25 biotech and pharma clients add to Incyte's customer list, estimates put Proteome's 2000 subscription revenues at less than $\$ 5$ million, and analysts note that Incyte has already heavily penetrated the big pharma market. "While this adds a little more value to their dataset, I wouldn't call it a great acquisition," says Gruntal \& Co. (New York) analyst Darren Mac. "Incyte is trying to diversify its content base, but to create value what it really needs to do is to move downstream into drug discovery and development." According to Proteome, Incyte will continue to make the BioKnowledge library, which allows researchers to compare genetic data across different species, freely available to Proteome's academic customers.

$C M$

\section{Accidental weapon}

Researchers at the Cooperative Research Centre (CRC) for the Biological Control of Pest Animals (Canberra, Australia) have accidentally engineered a "killer virus," wiping out all of their experimental mice. To render mice and rats sterile and ultimately decrease rodent infestations of grain crops, CRC scientists inserted a gene for interleukin-4 (IL-4) into a mousepox virus with the hope of stimulating antibodies against eggs in mice subsequently injected with the virus. However, the engineered virus became much more virulent than intended, killing all the rodents treated by suppressing cell-mediated responses against viral infection. Concerns that a similar modification of the smallpox virus could prove just as lethal to humans has renewed calls for a strengthening of the 1972 Biological and Toxins Weapons Convention (Nat. Biotechnol. 18, 806, 2000). In a 15 January letter to The Australian, CRC CEO Bob Seamark stated: "the best way to avoid misuse of this technique by unethical persons was to alert the world to it." A report on the discovery will be published in February's Journal of Virology. 